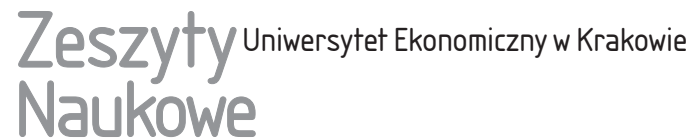

\section{Porównanie struktury mieszkan w obrocie w wybranych miastach północno-zachodniej Polski}

\section{Streszczenie}

Rzeczoznawca majątkowy w procesie wyceny nieruchomości niejednokrotnie jest zmuszony do wyboru rynków podobnych, które terytorialnie wykraczają poza granice administracyjne jednego miasta. Kryterium podobieństwa wybranych miast mogą być zarówno czynniki demograficzne, jak i wskaźniki ekonomiczne. Jednym z obszarów dyskusji nad podobieństwem rynków może być analiza porównawcza struktur mieszkań w obrocie na wybranych rynkach. Wynik takiego porównania może potwierdzić podobieństwo rynków, a w praktyce fakt podobieństwa struktur można wykorzystywać do dalszych analiz i wyceny.

Celem artykułu jest porównanie struktur mieszkań w obrocie w dwóch wybranych miastach północno-zachodniej Polski. W artykule wybrano do analizy rynek mieszkaniowy Szczecina i Bydgoszczy, kierując się przy wyborze zarówno podobną liczbą ludności, jak i skalą transakcji mieszkaniami. Z uwagi na warunki demograficzne Szczecin i Bydgoszcz spełniają kryteria podobieństwa, co pozwala również na porównanie rynków mieszkaniowych tych miast, ściśle związanych z czynnikami demograficznymi. Do porównania wykorzystano dane dotyczące transakcji mieszkaniami w dwóch latach - 2009 (początek kryzysu na rynku nieruchomości) oraz 2015 (ostatni pełny rok,

Iwona Foryś, Uniwersytet Szczeciński, Instytut Ekonometrii i Statystyki, Katedra Badań Operacyjnych i Zastosowań Matematyki w Ekonomii, 71-101 Szczecin, ul. Mickiewicza 64, e-mail: forys@wneiz.pl

Barbara Batóg, Uniwersytet Szczeciński, Instytut Ekonometrii i Statystyki, Katedra Badań Operacyjnych i Zastosowań Matematyki w Ekonomii, 71-101 Szczecin, ul. Mickiewicza 64, e-mail: barbara.batog@wneiz.pl 
dla którego możliwe było zgromadzenie danych). Każdą transakcję opisano za pomocą zestawu zmiennych: data transakcji, cena, powierzchnia, lokalizacja oraz inne dostępne dane charakteryzujące rynek mieszkaniowy. W analizie wykorzystano miary entropii i podobieństwa struktur.

Słowa kluczowe: rynek mieszkaniowy, porównanie struktur, miary entropii, wycena.

Klasyfikacja JEL: C50, R30.

\section{Wprowadzenie}

Fundamentalnym problemem procesu szacowania nieruchomości jest pojęcie podobieństwa. Podobieństwo w ujęciu matematycznym (geometrii) jest jednoznaczne, podczas gdy w naukach społecznych nie jest tak precyzyjne [Cieślak i Jasiński 1979]. Może być rozumiane jako miara określająca stopień podobieństwa, czyli miara przynależności do grup obiektów o tych samych własnościach. Na rynku nieruchomości podobieństwo obiektów (nieruchomości) nie jest precyzyjnie zdefiniowane $w$ aktach prawnych, co powoduje również problemy natury praktycznej, gdyż rzeczoznawca majątkowy w procesie szacowania wybiera obiekty podobne, kierując się najczęśsiej intuicją, a nie obiektywnymi przesłankami [Zyga 2009]. Z metodyki wyceny nieruchomości wynika, że są to obiekty różniące się najmniejszą liczbą cech porównawczych [Foryś 2010]. Podobieństwo obiektów nie dotyczy jednak wyłącznie doboru konkretnych nieruchomości do zbioru, który stanowi podstawę wyceny. W praktyce rzeczoznawca majątkowy niejednokrotnie jest zmuszony do wyboru rynków podobnych, które terytorialnie wykraczają poza granice administracyjne jednego miasta. Rynki podobne (rynki równolegle) są dobierane przez rzeczoznawcę na podstawie indywidualnie ustalonych kryteriów. Jako kryterium podobieństwa mogą być przyjęte czynniki ekonomiczne (wskaźniki gospodarcze, wskaźniki rynku pracy, kondycji gospodarstw domowych itp.), czynniki demograficzne oraz lokalna polityka inwestycyjna [Batóg i Foryś 2013]. Wybór kryterium porównawczego zależy od rodzaju szacowanej nieruchomości i zasięgu terytorialnego branych pod uwagę rynków podobnych. W przypadku nieruchomości mieszkalnych należy zwrócić szczególną uwagę na czynniki demograficzne i warunki życia gospodarstw domowych. Można również porównywać rynki z uwagi na zasoby mieszkaniowe lub ceny mieszkań, które są wypadkową popytu i podaży na tym rynku.

Celem artykułu jest porównanie struktur mieszkań w obrocie ze względu na cechy charakteryzujące te mieszkania na dwóch lokalnych rynkach północno-zachodniej Polski: Szczecina i Bydgoszczy. Wybór miast wynikał z podobieństwa obu miast w zakresie poziomu rozwoju społeczno-gospodarczego, zasobów mieszkaniowych oraz skali transakcji mieszkaniami. 


\section{Metodyka badania}

Podobieństwo w naukach społecznych jest często identyfikowane z miarą podobieństwa, czyli odległością między badanymi obiektami. Obiekty są podobne jeżeli w wyniku procedury klasyfikacyjnej znajdują się w tej samej klasie [Strahl 1986]. Badanie stopnia podobieństwa jednostek przestrzennych można ocenić, analizując strukturę zmiennych charakteryzujących zjawiska dotyczące tych obiektów. Obok klasycznych metod analizy struktur można do badania zróżnicowań strukturalnych jednostek przestrzennych wykorzystać również metody oparte na miarach entropii i dywergencji. Entropia w przypadku rozkładu empirycznego ,informuje o stopniu niepewności, związanym ze względnym występowaniem określonego wariantu cechy X w badanej zbiorowości" [Wędrowska 2012, s. 22]. Do badania rozbieżności struktur służą natomiast liczne miary dywergencji.

W artykule, w celu porównania rozkładów analizowanych zmiennych, wykorzystano następujące miary: względny indeks Herfindahla-Hirschmana oraz względną entropię. Indeks Herfindahla-Hirschmana $(H)$ wyraża się wzorem [Ekonometria przestrzenna... 2010]:

$$
H=\sum_{k=1}^{n} u_{k}^{2},
$$

gdzie:

$n$ - liczba klas,

$k$ - numer klasy,

$u_{k}$ - udział obiektów z $k$-tej klasy w całkowitej liczbie obiektów.

Indeks Herfindahla-Hirschmana przyjmuje maksymalną wartość 1, a jego minimalna wartość zależy od liczby klas. $Z$ tego względu wartości $H$ unormowano na przedział $\langle 0,1\rangle$ - otrzymano względny indeks Herfindahla-Hirschmana.

W pracy wykorzystano również jedną z miar entropii wyrażoną wzorem [Wędrowska 2012, Batóg 2008]:

gdzie:

$$
E=-\sum_{k=1}^{n} u_{k} \log _{2} u_{k}
$$

$n$ - liczba klas,

$k$ - numer klasy,

$u_{k}$ - udział obiektów z $k$-tej klasy w całkowitej liczbie obiektów.

Entropia ma najmniejszą wartość 0 , ale największa wartość zależy od liczby klas. Z tego względu posłużono się unormowaniem entropii na przedział $\langle 0,1\rangle$ względną entropią.

Zastosowano również dwie miary dywergencji - odległość miejską oraz względną odległość Canberra [Gatnar i Walesiak 2004, Młodak 2006, Gordon 1999]. Odległość miejska wyraża się wzorem: 


$$
M=\sum_{k=1}^{n}\left|u_{1 k}-u_{2 k}\right|
$$

gdzie:

$n-$ liczba klas,

$k$ - numer klasy,

$u_{1 k}, u_{2 k}$ - udział obiektów z $k$-tej klasy w całkowitej liczbie obiektów odpowiednio dla próby 1 i próby 2 .

W przypadku odległości struktur metryka miejska przyjmuje wartości z przedziału $\langle 0,2\rangle$. Odległość Canberra przyjmuje wartości z przedziału $\langle 0, n\rangle$, dlatego zastosowano względną odległość Canberra, która przyjmuje wartości z przedziału $\langle 0,1\rangle$ :

gdzie:

$$
C=\frac{1}{n} \sum_{k=1}^{n} \frac{\left|u_{1 k}-u_{2 k}\right|}{u_{1 k}+u_{1 k}},
$$

$n-$ liczba klas,

$k$ - numer klasy,

$u_{1 k}, u_{2 k}$ - udział obiektów z $k$-tej klasy w całkowitej liczbie obiektów odpowiednio dla próby 1 i próby 2 .

Jako miarę podobieństwa struktur zastosowano wskaźnik Chomątowskiego-Sokołowskiego [Malina 2004] wyrażający się wzorem:

gdzie:

$$
C S=\frac{1}{n} \sum_{k=1}^{n} \min \left(u_{1 k}, u_{2 k}\right)
$$

$n$ - liczba klas,

$k$ - numer klasy,

$u_{1 k}, u_{2 k}$ - udział obiektów z $k$-tej klasy w całkowitej liczbie obiektów odpowiednio dla próby 1 i próby 2.

Wskaźnik Chomątowskiego-Sokołowskiego przyjmuje wartości z przedziału $\langle 0,1\rangle$. Im wyższa jest wartość tego wskaźnika, tym większe jest podobieństwo badanych prób.

Badanie uzupełniono o porównanie rozkładów empirycznych do rozkładu równomiernego za pomocą testu zgodności Kołmogorowa, a także porównanie rozkładów między sobą za pomocą testu zgodności Kołmogorowa-Smirnowa [Domański 1990]. To drugie porównanie przeprowadzono parami, tzn. pomiędzy miastami oraz pomiędzy latami.

\section{Dane wykorzystane w badaniu}

Do porównania struktur cech charakteryzujących obrót mieszkaniami na lokalnych rynkach wybrano Szczecin oraz Bydgoszcz. Jako kryterium wyboru 
tych rynków przyjęto poziom rozwoju społeczno-gospodarczego, stan i strukturę zasobów mieszkaniowych oraz skalę transakcji na rynku mieszkaniowym. Dane pozyskano z aktów notarialnych (badanie pełne), wybierając do porównania dwa lata: początek kryzysu na rynku nieruchomości (2009 r.) oraz ostatni pełny rok, dla którego możliwe było zgromadzenie danych (2015 r.). Dla każdego badanego rynku dysponowano danymi z aktów notarialnych, w których transakcje opisano za pomocą zmiennych:

- data zawarcia umowy (dd-mm-rrrr),

- prawo do lokalu mieszkalnego: odrębna własność, spółdzielcze własnościowe prawo,

- liczba pokoi (1, 2, 3, 4, 5 i więcej),

- powierzchnia użytkowa lokalu $\left(\mathrm{m}^{2}\right)$,

- cena transakcyjna (zł),

- cena jednostkowa $\left(\mathrm{z} / \mathrm{m}^{2}\right)$.

Analizowano 1037 transakcji w Bydgoszczy i 1738 transakcji w Szczecinie przeprowadzonych w 2009 r. oraz 897 transakcji w Bydgoszczy i 2183 transakcje w Szczecinie przeprowadzone w 2015 r. Dla każdej zmiennej mierzonej na skali ilorazowej oraz miasta i roku badania wyznaczono podstawowe statystyki opisowe, wykorzystano miary entropii, dywergencji oraz podobieństwa struktur. $\mathrm{W}$ przypadku wszystkich zmiennych strukturę zaprezentowano $\mathrm{w}$ formie tabelarycznej i na wykresach.

W obu miastach w badanych latach w obrocie przeważała odrębna własność mieszkań, przy czym w 2009 r. w Bydgoszczy takich mieszkań sprzedano 65,96\%, podczas gdy w 2015 r. już 88,63\%. W Szczecinie w obu badanych latach obrót tymi mieszkaniami był mniej zróżnicowany: ponad 55\% mieszkań sprzedano w 2009 r., a blisko 64\% w 2015 r. (tabela 1).

Tabela 1. Struktura mieszkań według zmiennej ,,prawo do lokalu” (w \%)

\begin{tabular}{|l|c|c|c|c|}
\hline \multirow{2}{*}{ Rodzaj prawa } & \multicolumn{2}{|c|}{ Bydgoszcz } & \multicolumn{2}{c|}{ Szczecin } \\
\cline { 2 - 5 } & $2009 \mathrm{r}$. & $2015 \mathrm{r}$. & $2009 \mathrm{r}$. & $2015 \mathrm{r}$. \\
\hline Prawo spółdzielcze & 34,04 & 11,37 & 44,65 & 36,10 \\
\hline Prawo własnościowe & 65,96 & 88,63 & 55,35 & 63,90 \\
\hline
\end{tabular}

Źródło: obliczenia własne.

Większy obrót prawem własności w 2015 r. w stosunku do 2009 r. wynikał z trwających jeszcze procesów przekształceń własnościowych mieszkań spółdzielczych w odrębną własność. W 2009 r. mieszkania spółdzielcze w Szczecinie stanowiły $42 \%$ zasobów mieszkaniowych, a w 2013 r. już tylko 37\%. Tendencję odwrotną odnotowano w przypadku udziału mieszkań we własności osób fizycznych: 33,5\% w 2009 r. oraz 39,4\% w 2013 r. W ciągu wskazanych 
lat w Bydgoszczy również zmalał udział mieszkań spółdzielczych w zasobach mieszkaniowych ogółem z 43,7\% w 2009 r. do 39,2\% w 2013 r. oraz wzrósł udział mieszkań we własności osób fizycznych z 36,5\% w 2009 r. do 43,9\% w 2013 r. Wskazane zmiany w strukturze własności w obu miastach były również wynikiem nowych inwestycji, a nie tylko przekształceń własnościowych.

$\mathrm{W}$ badanych latach i w obu miastach $\mathrm{w}$ obrocie przeważały mieszkania dwupokojowe (tabela 2). W zależności od roku stanowiły one 40-45\% mieszkań w obrocie. Na analizowanych rynkach najmniej sprzedawano mieszkań dużych, o pięciu i więcej pokojach. Mimo iż wydaje się, że rynek kawalerek (mieszkań jednopokojowych) jest bardzo aktywny, to w Bydgoszczy w obu latach więcej sprzedawano mieszkań trzypokojowych niż kawalerek, natomiast w Szczecinie tylko w 2015 r. udział mieszkań trzypokojowych w obrocie był wyższy niż jednopokojowych.

Tabela 2. Struktura mieszkań według zmiennej „liczba pokoi” (w \%)

\begin{tabular}{|c|c|c|c|c|}
\hline \multirow{2}{*}{ Liczba pokoi } & \multicolumn{2}{|c|}{ Bydgoszcz } & \multicolumn{2}{c|}{ Szczecin } \\
\cline { 2 - 5 } & $2009 \mathrm{r}$. & $2015 \mathrm{r}$. & $2009 \mathrm{r}$. & $2015 \mathrm{r}$. \\
\hline 1 & 19,58 & 15,72 & 23,48 & 21,67 \\
\hline 2 & 40,79 & 44,82 & 45,17 & 45,49 \\
\hline 3 & 32,50 & 32,22 & 18,76 & 26,07 \\
\hline 4 & 6,27 & 6,13 & 10,01 & 5,82 \\
\hline 5 & 0,87 & 1,11 & 2,59 & 0,96 \\
\hline
\end{tabular}

Źródło: obliczenia własne.

Kolejną analizowaną zmienną jest „,powierzchnia lokalu”. Badane rozkłady charakteryzują się nieznaczną asymetrią, w każdym przypadku mediana oraz średnia powierzchnia mieszkania oscylują blisko $50 \mathrm{~m}^{2}$. Znaczny jest rozstęp powierzchni sprzedanych mieszkań - jego wartość mieści się w przedziale 148-227 m² i wskazuje na znaczne zróżnicowanie powierzchni mieszkań w obrocie. Należy jednak zaznaczyć, że powierzchnia połowy sprzedanych mieszkań w każdym analizowanym przypadku mieściła się w przedziale $37-50 \mathrm{~m}^{2}$ (tabela 3).

W badanych latach oraz na badanych rynkach najczęściej w obrocie były mieszkania o powierzchni $40-50 \mathrm{~m}^{2}$. Prezentowane na wykresach rozkłady powierzchni w kolejnych latach dla Bydgoszczy i Szczecina charakteryzuje duże podobieństwo (rys. 1-4).

Drugą grupą najczęściej sprzedawanych mieszkań (z wyjątkiem Szczecina w 2009 r.) są lokale o powierzchni 30-40 $\mathrm{m}^{2}$. Najmniej w obrocie było mieszkań bardzo małych, których powierzchnia nie przekraczała nawet $20 \mathrm{~m}^{2}$. Struktura sprzedawanych mieszkań jest konsekwencją zasobu mieszkaniowego w Polsce, 
w szczególności efektów nowych inwestycji. W okresie recesji ponownie popularne na rynku stały się małe mieszkania, na co wpływ miały również limity powierzchni w programach rządowych wspierających budownictwo mieszkaniowe. Analizowane rynki różniły się ceną jednostkową sprzedanych mieszkań.

Tabela 3. Parametry opisowe dla zmiennej „,powierzchnia lokalu” ( $\mathrm{w} \mathrm{m}^{2}$ )

\begin{tabular}{|l|r|r|r|r|}
\hline \multirow{2}{*}{\multicolumn{1}{|c|}{ Statystyki opisowe }} & \multicolumn{2}{c|}{ Bydgoszcz } & \multicolumn{2}{c|}{ Szczecin } \\
\cline { 2 - 5 } & $2009 \mathrm{r}$. & 2015 r. & 2009 r. & 2015 r. \\
\hline Minimum & 16,33 & 13,61 & 16,80 & 8,50 \\
\hline Maksimum & 168,17 & 239,92 & 165,56 & 181,18 \\
\hline Rozstęp & 151,84 & 226,31 & 148,76 & 172,68 \\
\hline Średnia & 50,62 & 51,64 & 51,05 & 52,25 \\
\hline Odchylenie standardowe & 17,19 & 18,47 & 19,22 & 20,38 \\
\hline Współczynnik zmienności & 33,97 & 35,77 & 37,65 & 39,01 \\
\hline Współczynnik skośności & 1,60 & 2,51 & 1,30 & 1,54 \\
\hline Mediana & 48,90 & 49,56 & 48,00 & 48,89 \\
\hline Dolny kwartyl & 37,90 & 39,88 & 37,30 & 37,62 \\
\hline Górny kwartyl & 60,42 & 60,51 & 59,90 & 62,50 \\
\hline
\end{tabular}

Źródło: obliczenia własne.

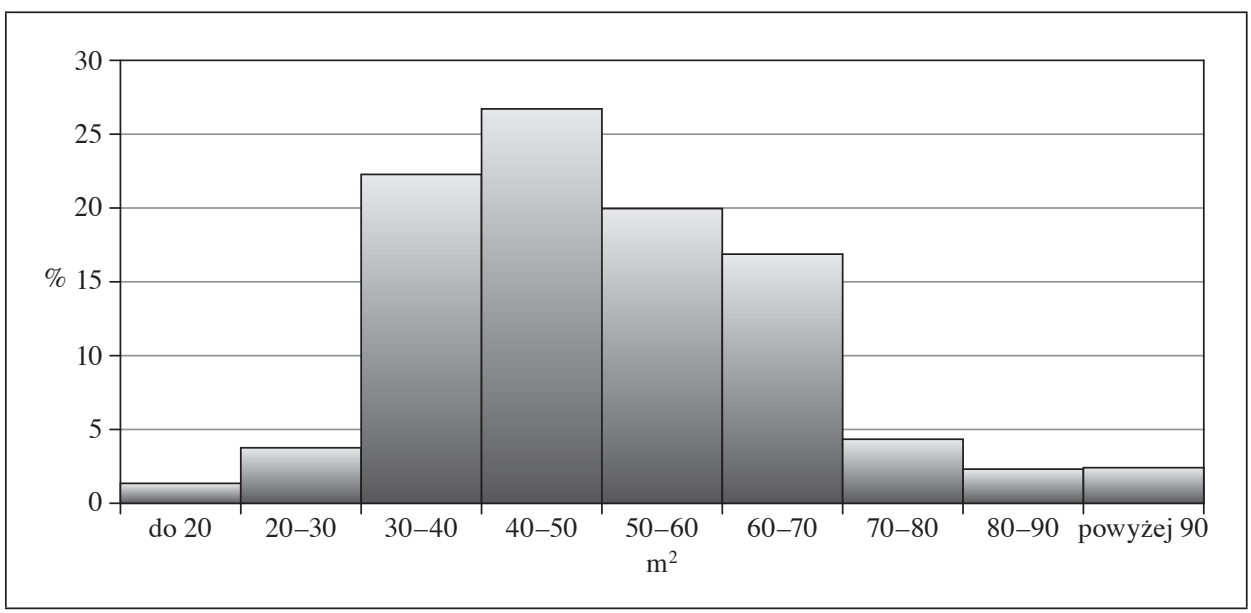

Rys. 1. Struktura mieszkań według zmiennej „powierzchnia lokalu” ( $\left.\mathrm{w} \mathrm{m}^{2}\right)$ w Bydgoszczy w 2009 r.

Źródło: obliczenia własne.

W obu miastach średnie ceny transakcyjne w 2013 r. spadły w stosunku do 2009 r., jednak w Szczecinie spadek cen był wyższy (11\%) niż w Bydgoszczy (5\%). 
Połowa zawartych transakcji w Bydgoszczy w 2009 r. dotyczyła cen jednostkowych z przedziału 3,2-4 tys. zł/m², podczas gdy w $2015 \mathrm{r}$. z przedziału 3-4 tys. zł/m². W Szczecinie odpowiednio ceny jednostkowe połowy transakcji mieściły się w przedziale $3,8-4,8$ tys. zł $/ \mathrm{m}^{2} \mathrm{w} 2009 \mathrm{r}$. oraz w przedziale $3,3-4,4$ tys. $\mathrm{zł} / \mathrm{m}^{2}$ w 2015 r. (tabela 4).

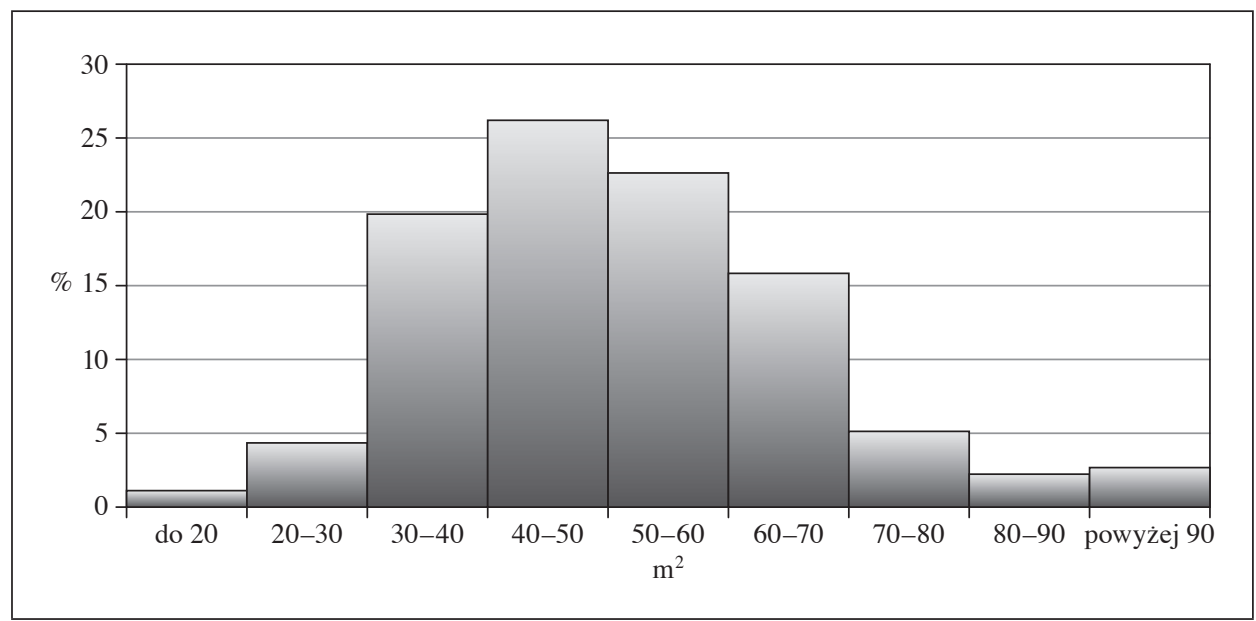

Rys. 2. Struktura mieszkań według zmiennej „powierzchnia lokalu” ( $\left(\mathrm{w} \mathrm{m}^{2}\right)$ w Bydgoszczy w $2015 \mathrm{r}$.

Źródło: obliczenia własne.

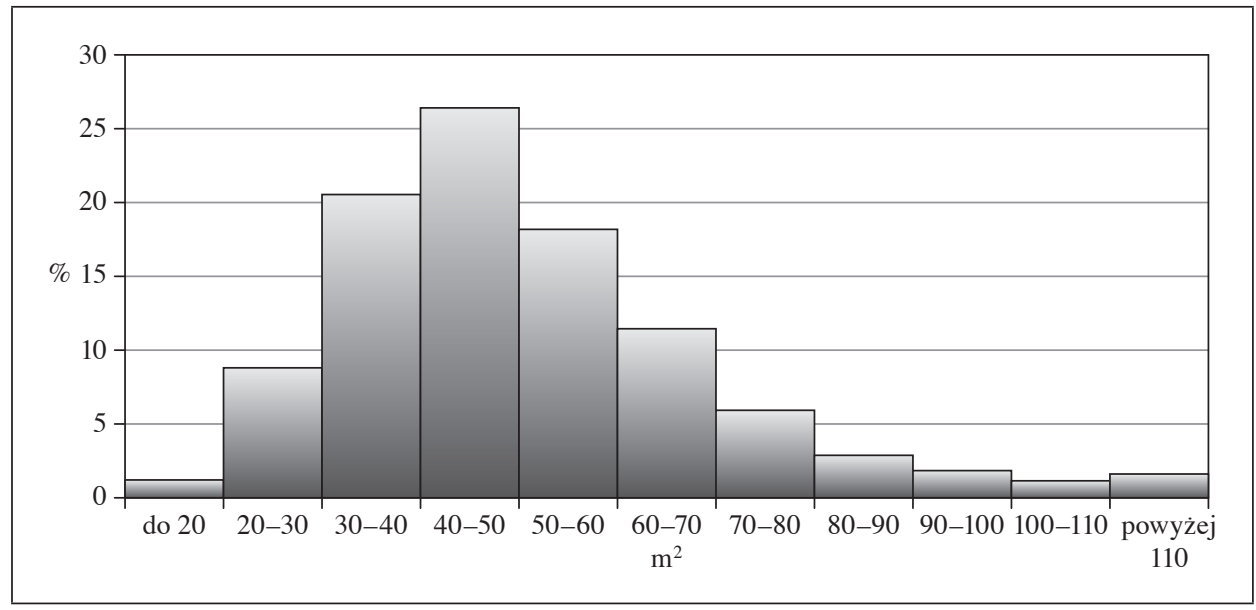

Rys. 3. Struktura mieszkań według zmiennej ,powierzchnia lokalu” ( $\left(\mathrm{w}^{2}\right)$ w Szczecinie w 2009 r.

Źródło: obliczenia własne. 


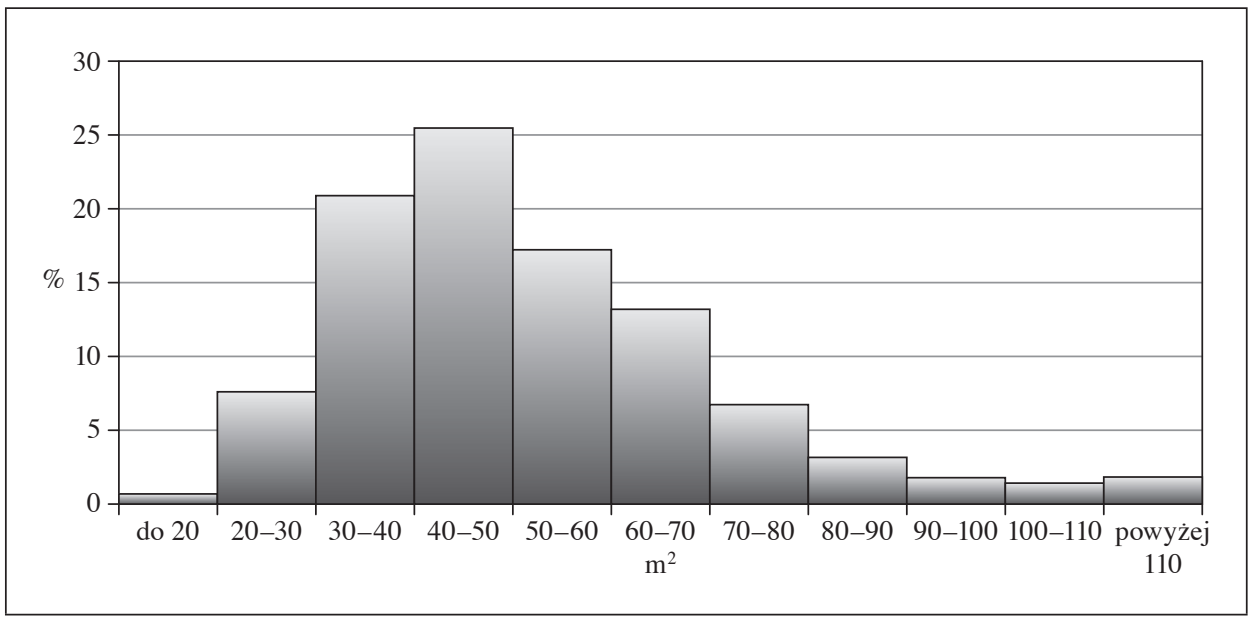

Rys. 4. Struktura mieszkań według zmiennej ,,powierzchnia lokalu” (w m²) w Szczecinie w 2015 r.

Źródło: obliczenia własne.

Rozkłady ceny jednostkowej we wszystkich analizowanych przypadkach są symetryczne (rys. 5-8). W Bydgoszczy najczęściej sprzedawano mieszkania za 3,5-4 tys. zł $/ \mathrm{m}^{2}$ w 2009 r. oraz za 3-3,5 tys. zł $/ \mathrm{m}^{2}$ w 2015 r., natomiast w Szczecinie najczęściej sprzedawano mieszkania za 4-4,5 tys. zł $/ \mathrm{m}^{2}$ w 2009 r. oraz za 3,5-4 tys. zł $/ \mathrm{m}^{2}$ w $2015 \mathrm{r}$. W badanych latach w obu miastach nastąpiło przesunięcie przedziału najczęstszych cen jednostkowych o $500 \mathrm{zł} / \mathrm{m}^{2}$.

Tabela 4. Parametry opisowe dla zmiennej „,cena $1 \mathrm{~m}^{2}$ ” (w zł)

\begin{tabular}{|l|r|r|r|r|}
\hline \multirow{2}{*}{\multicolumn{1}{c|}{ Statystyki opisowe }} & \multicolumn{2}{c|}{ Bydgoszcz } & \multicolumn{2}{c|}{ Szczecin } \\
\cline { 2 - 5 } & $2009 \mathrm{r}$. & \multicolumn{1}{c|}{$2015 \mathrm{r}}$. & \multicolumn{1}{c|}{$2009 \mathrm{r}}$. & \multicolumn{1}{c|}{$2015 \mathrm{r}}$. \\
\hline Minimum & 1184,83 & 1056,25 & 636,33 & 560,42 \\
\hline Maksimum & 7013,34 & 6983,53 & 11229,99 & 9220,76 \\
\hline Rozstęp & 5828,51 & 5927,28 & 10593,66 & 8660,33 \\
\hline Średnia & 3640,52 & 3461,73 & 4310,96 & 3843,08 \\
\hline Odchylenie standardowe & 749,70 & 804,54 & 991,40 & 941,84 \\
\hline Współczynnik zmienności & 20,59 & 23,24 & 23,00 & 24,51 \\
\hline Współczynnik skośności & 0,18 & 0,39 & 0,17 & 0,04 \\
\hline Mediana & 3606,24 & 3381,83 & 4337,28 & 3865,83 \\
\hline Dolny kwartyl & 3213,61 & 2969,98 & 3832,64 & 3312,69 \\
\hline Górny kwartyl & 4043,65 & 3924,37 & 4826,31 & 4390,65 \\
\hline
\end{tabular}

Źródło: obliczenia własne. 


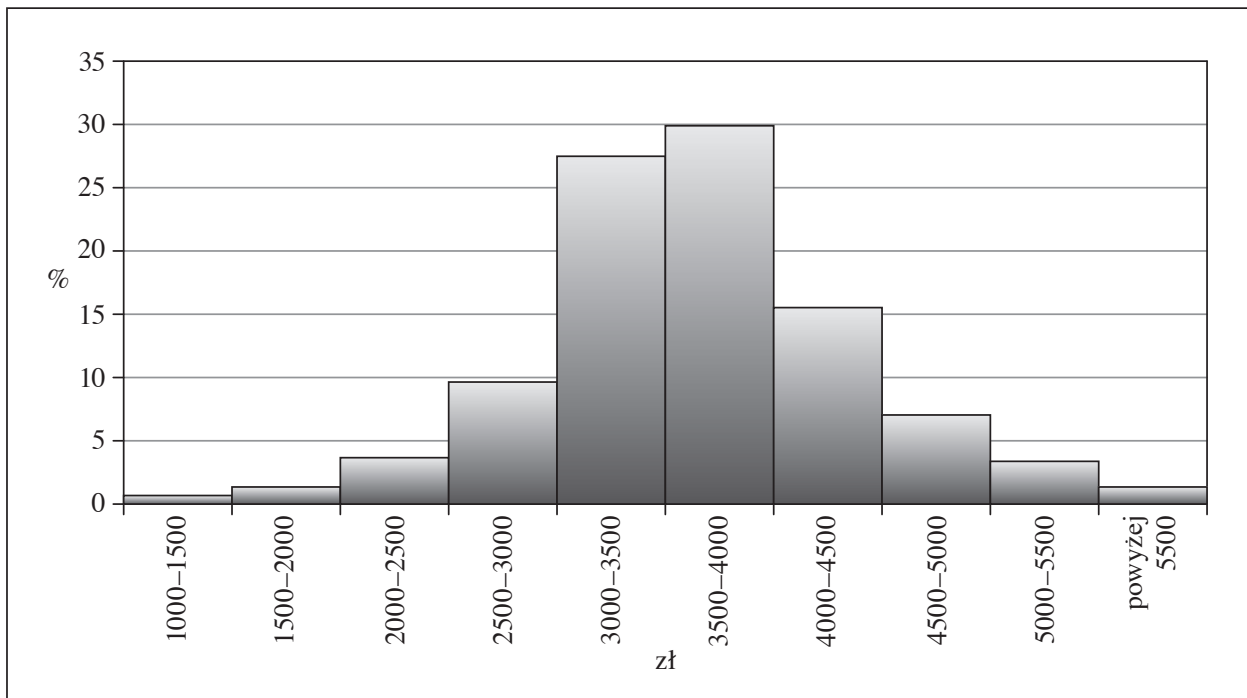

Rys. 5. Struktura mieszkań według zmiennej „,ena $1 \mathrm{~m}^{2}$ ” (w zł) w Bydgoszczy w 2009 r.

Źródło: obliczenia własne.

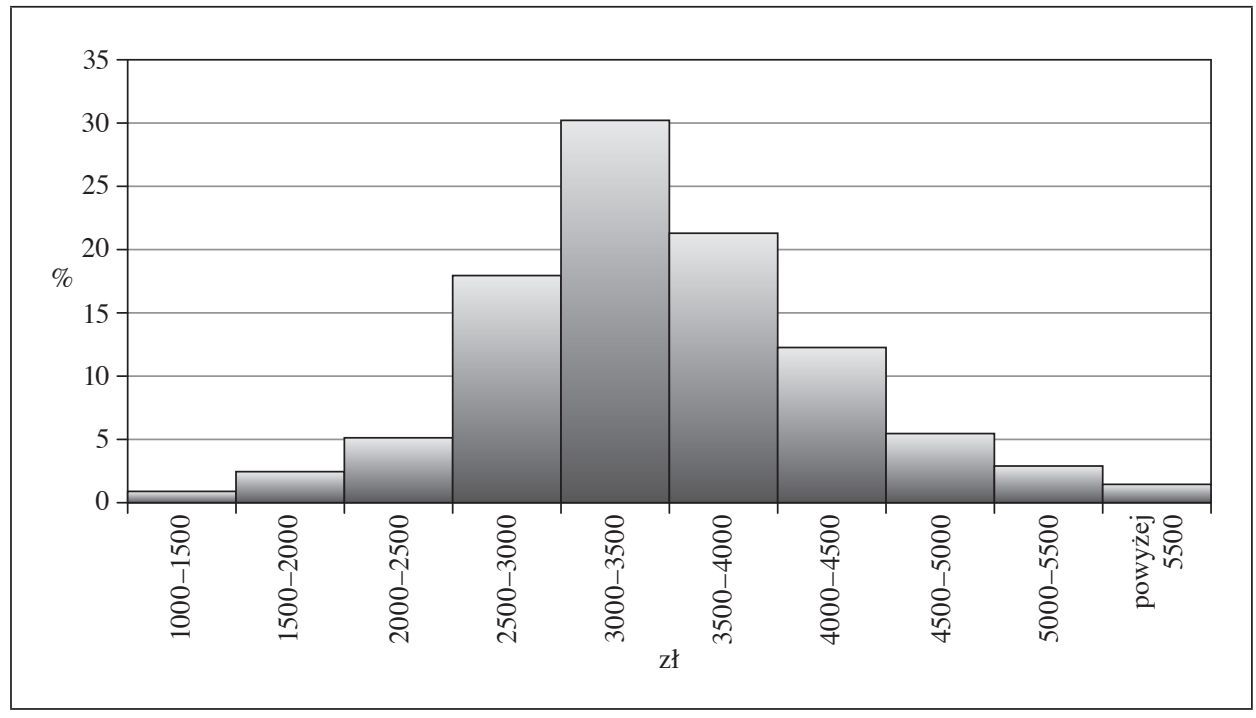

Rys. 6. Struktura mieszkań według zmiennej „cena $1 \mathrm{~m}^{2}$ ” (w zł) w Bydgoszczy w $2015 \mathrm{r}$.

Źródło: obliczenia własne. 


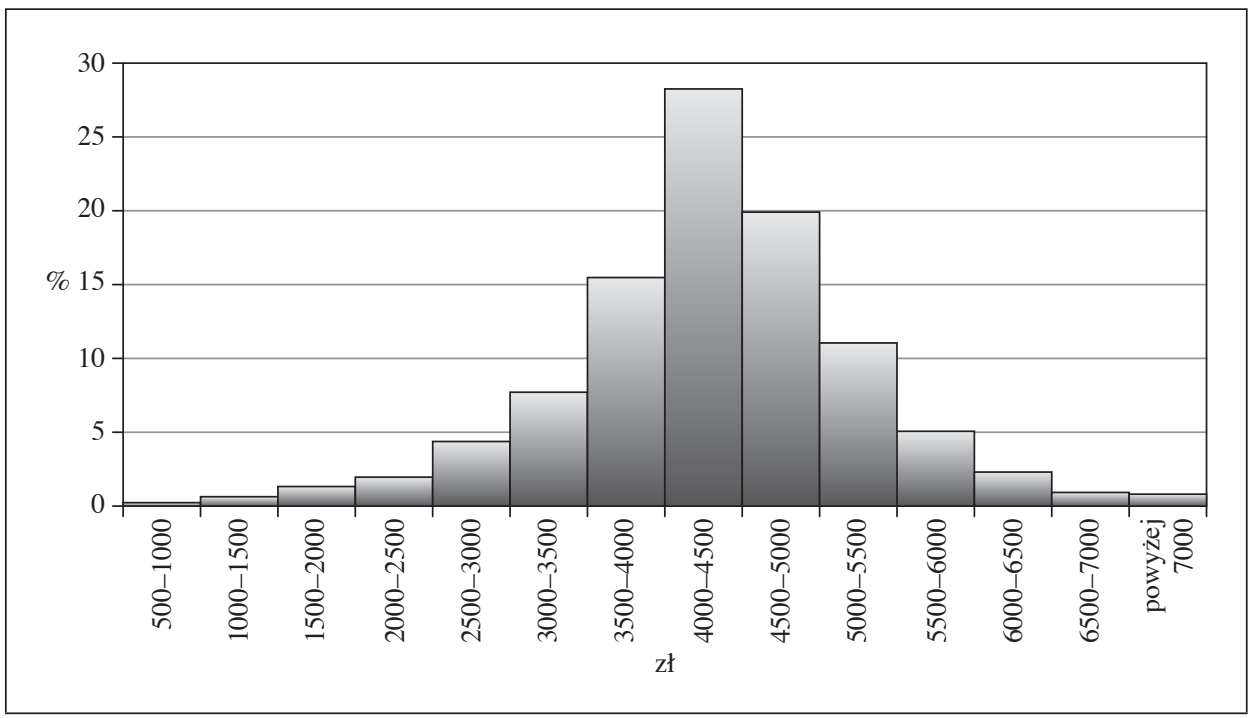

Rys. 7. Struktura mieszkań według zmiennej „,cena $1 \mathrm{~m}^{2}$ ” (w zł) w Szczecinie w 2009 r.

Źródło: obliczenia własne.

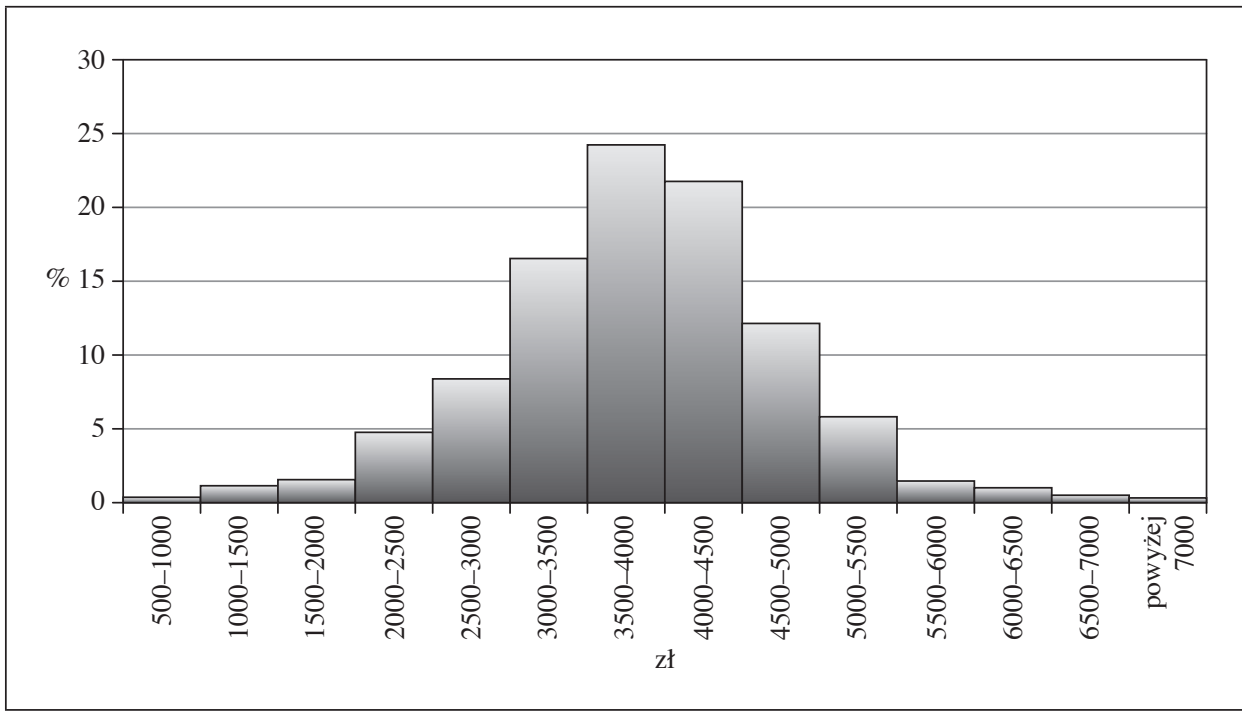

Rys. 8. Struktura mieszkań według zmiennej „cena $1 \mathrm{~m}^{2}$ ” (w zł) w Szczecinie w 2015 r.

Źródło: obliczenia własne. 


\section{Miary entropii, dywergencji i podobieństwa}

Dla każdej analizowanej zmiennej wyznaczono miarę względnej entropii, przy czym wartości względnej entropii większe i bliższe 1 wskazują na to, że rozkład jest bliski równomiernemu. Względna entropia we wszystkich analizowanych przypadkach dla zmiennej „liczba pokoi” przyjmuje wartości bliskie 0,8, co wskazuje na rozkład równomierny (tabela 5). Powyższy wniosek potwierdza względny indeks Herfindahla-Hirschmana (tabela 5), nieprzekraczający we wszystkich analizowanych przypadkach wartości 0,17 (indeks przyjmuje wartości z przedziału od 0 do 1 oraz im jest mniejszy, tym rozkład jest bardziej równomierny).

Dodatkowo weryfikowano hipotezę o równomierności rozkładu testem Kołmogorowa. W przypadku wartości statystyki większej od 1,36 (poziom istotności 0,05 ) odrzucamy hipotezę o równomierności rozkładu na korzyść hipotezy alternatywnej o braku równomierności rozkładu. Dla zmiennych ,powierzchnia lokalu” oraz „cena $1 \mathrm{~m}^{2}$ ” wartość statystyki testowej w każdym przypadku znacznie przekroczyła wskazaną wartość krytyczną. Dla tych zmiennych oraz badanych lat i rynków nie można uznać, że rozkłady są równomierne (tabela 5).

Tabela 5. Mierniki zróżnicowania struktur mieszkań według wybranych zmiennych

\begin{tabular}{|l|c|c|c|c|}
\hline \multirow{2}{*}{ Miernik } & \multicolumn{2}{c|}{ Bydgoszcz } & \multicolumn{2}{c|}{ Szczecin } \\
\cline { 2 - 5 } & 2009 r. & 2015 r. & 2009 r. & 2015 r. \\
\hline \multicolumn{5}{|c|}{ Liczba pokoi } \\
\hline Względna entropia & 0,786 & 0,768 & 0,831 & 0,777 \\
\hline $\begin{array}{l}\text { Względny indeks Herfindahla- } \\
\text {-Hirschmana }\end{array}$ & 0,143 & 0,167 & 0,131 & 0,157 \\
\hline \multicolumn{5}{|c|}{ Powierzchnia lokalu } \\
\hline Względna entropia & 0,821 & 0,828 & 0,819 & 0,0822 \\
\hline $\begin{array}{l}\text { Względny indeks Herfindahla- } \\
\text {-Hirschmana }\end{array}$ & 0,093 & 0,089 & 0,088 & 0,085 \\
\hline Statystyka w teście Kołmogorowa & 7,82 & 6,98 & 13,36 & 14,26 \\
\hline \multicolumn{5}{|c|}{ Cena $1 \mathrm{~m}^{2}$} \\
\hline Względna entropia & 0,768 & 0,810 & 0,775 & 0,772 \\
\hline $\begin{array}{l}\text { Względny indeks Herfindahla- } \\
\text {-Hirschmana }\end{array}$ & 0,118 & 0,101 & 0,103 & 0,097 \\
\hline Statystyka w teście Kołmogorowa & 7,94 & 6,45 & 11,34 & 12,43 \\
\hline
\end{tabular}

Źródło: obliczenia własne. 
W następnej kolejności w celu porównania obu rynków i analizowanych zmiennych wyznaczono miary dywergencji (tabela 6).

Tabela 6. Miara dywergencji badanych rynków - odległość miejska

\begin{tabular}{|l|c|c|c|}
\hline \multicolumn{1}{|c|}{ Badane struktury } & Liczba pokoi & $\begin{array}{c}\text { Powierzchnia } \\
\text { lokalu }\end{array}$ & Cena $1 \mathrm{~m}^{2}$ \\
\hline Bydgoszcz 2009 r. - Bydgoszcz 2015 r. & 0,085 & 0,087 & 0,281 \\
\hline Szczecin 2009 r. - Szczecin 2015 r. & 0,153 & 0,071 & 0,506 \\
\hline Bydgoszcz 2009 r. - Szczecin 2009 r. & 0,275 & 0,183 & 0,825 \\
\hline Szczecin 2015 - Bydgoszcz 2015 r. & 0,132 & 0,177 & 0,490 \\
\hline
\end{tabular}

Źródło: obliczenia własne.

Tabela 7. Miara dywergencji badanych rynków - względna odległość Canberra (max. 1)

\begin{tabular}{|l|c|c|c|}
\hline \multicolumn{1}{|c|}{ Badane struktury } & Liczba pokoi & $\begin{array}{c}\text { Powierzchnia } \\
\text { lokalu }\end{array}$ & Cena $1 \mathrm{~m}^{2}$ \\
\hline Bydgoszcz 2009 r. - Bydgoszcz 2015 r. & 0,059 & 0,061 & 0,271 \\
\hline Szczecin 2009 r. - Szczecin 2015 r. & 0,186 & 0,070 & 0,304 \\
\hline Bydgoszcz 2009 r. - Szczecin 2009 r. & 0,227 & 0,178 & 0,517 \\
\hline Szczecin 2015 r. - Bydgoszcz 2015 r. & 0,074 & 0,183 & 0,387 \\
\hline
\end{tabular}

Źródło: obliczenia własne.

Najwyższa wartość miary wystąpiła w przypadku zmiennej „,ena $1 \mathrm{~m}^{2}$ ” dla Bydgoszczy i Szczecina w 2009 r. $(0,825)$, przy maksymalnej możliwej wartości 2,0. Oznacza to brak możliwości porównywania obu rynków mieszkaniowych z uwagi na strukturę cen transakcyjnych. W przypadku pozostałych zmiennych oraz lat i rynków miary dywergencji mają niskie wartości i można uznać podobieństwo analizowanych struktur mieszkań ze względu na te zmienne.

W tabeli 8 zamieszczono wartości miary Chomątowskiego-Sokołowskiego dla wybranych zmiennych. Potwierdzają one wyniki otrzymane przy zastosowaniu miary dywergencji. Dla zmiennych „liczba pokoi” i „powierzchnia lokalu” wartości miary są bardzo wysokie (bliskie 1), co świadczy o podobieństwie struktury mieszkań ze względu na te zmienne. Dla zmiennej „cena $1 \mathrm{~m}^{2}$ ” natomiast podobieństwo struktury mieszkań jest niższe, chociaż tylko w jednym przypadku (porównania Bydgoszczy i Szczecina w 2009 r.) wartość miary jest niższa niż 0,6.

Dodatkowo dla zmiennych ciągłych, czyli zmiennej ,powierzchnia lokalu” i zmiennej ,cena $1 \mathrm{~m}^{2}$ ”, przeprowadzono test Kołmogorowa-Smirnowa. Wartości statystyki testowej zamieszczono w tabeli 9. 
Tabela 8. Miara podobieństwa badanych rynków - miary Chomątowskiego-Sokołowskiego (max. 1)

\begin{tabular}{|l|c|c|c|}
\hline \multicolumn{1}{|c|}{ Badane struktury } & Liczba pokoi & $\begin{array}{c}\text { Powierzchnia } \\
\text { lokalu }\end{array}$ & Cena $1 \mathrm{~m}^{2}$ \\
\hline Bydgoszcz 2009 r. - Bydgoszcz 2015 r. & 0,957 & 0,957 & 0,859 \\
\hline Szczecin 2009 r. - Szczecin 2015 r. & 0,924 & 0,963 & 0,747 \\
\hline Bydgoszcz 2009 r. - Szczecin 2009 r. & 0,863 & 0,906 & 0,588 \\
\hline Szczecin 2015 r. - Bydgoszcz 2015 r. & 0,934 & 0,908 & 0,755 \\
\hline
\end{tabular}

Źródło: obliczenia własne.

Tabela 9. Statystyka testowa w teście zgodności Kołmogorowa-Smirnowa

\begin{tabular}{|l|c|c|}
\hline \multicolumn{1}{|c|}{ Badane struktury } & Powierzchnia lokalu & Cena $1 \mathrm{~m}^{2}$ \\
\hline Bydgoszcz 2009 r. - Bydgoszcz 2015 r. & 0,569 & 3,030 \\
\hline Szczecin 2009 r. - Szczecin 2015 r. & 1,017 & 7,865 \\
\hline Bydgoszcz 2009 r. - Szczecin 2009 r. & 1,249 & 10,450 \\
\hline Szczecin 2015 r. - Bydgoszcz 2015 r. & 1,236 & 6,021 \\
\hline
\end{tabular}

Źródło: obliczenia własne.

Otrzymane wyniki porównano z wartością krytyczną 1,36 (poziom istotności 0,05). Wyniki testu Kołmogorowa-Smirnowa potwierdzają zatem, że rozkłady powierzchni mieszkań sprzedawanych w Szczecinie i Bydgoszczy są podobne, natomiast rozkłady ceny $1 \mathrm{~m}^{2}$ są różne.

\section{Podsumowanie}

Na badanych rynkach najczęściej w obrocie były mieszkania dwupokojowe, o powierzchni 40-50 $\mathrm{m}^{2}$. Potwierdza to typową dla polskiego rynku mieszkaniowego cechę [Foryś 2011]. W badanych latach w obu miastach miał miejsce spadek cen. Nastąpiło przesunięcie przedziału najczęstszych cen jednostkowych o $500 \mathrm{zł} / \mathrm{m}^{2}$. Rozkłady ceny jednostkowej oraz powierzchni sprzedanych mieszkań we wszystkich analizowanych przypadkach są prawie symetryczne. Dla zmiennych ,liczba pokoi”, ,powierzchnia lokalu”, ,cena $1 \mathrm{~m}^{2}$ ” oraz dla badanych lat i rynków nie można uznać, że rozkłady są równomierne.

Zastosowane miary okazały się przydatne dla założonego celu badania. Dywergencja struktur na dość wysokim poziomie wystąpiła w przypadku zmiennej „,cena $1 \mathrm{~m}^{2}$ ” dla Bydgoszczy i Szczecina w 2009 r. Dywergencja struktur na umiarkowanym poziomie wystąpiła w przypadku zmiennej ,cena $1 \mathrm{~m}^{2}$ ” dla 
pozostałych porównań. Rozkłady zmiennej, „powierzchnia lokalu” były do siebie podobne we wszystkich analizowanych przypadkach.

\section{Literatura}

Batóg J. [2008], Struktura polskiej gospodarki - analiza koncentracji i specjalizacji sektorowej, „Studia i Prace Wydziału Nauk Ekonomicznych i Zarządzania Uniwersytetu Szczecińskiego", nr 11.

Batóg B., Foryś I. [2013], The Analysis of Spatial Stability of Prices on the Secondary Housing Market, ,Acta Universitatis Lodziensis Folia Oeconomica”, nr 292.

Cieślak M., Jasiński R. [1979], Miara podobieństwa funkcji, „Przegląd Statystyczny”, vol. XXVI, nr 3/4.

Domański C. [1990], Testy statystyczne, PWE, Warszawa.

Ekonometria przestrzenna. Metody i modele analizy danych przestrzennych [2010], red. B. Suchecki, Wydawnictwo C.H. Beck, Warszawa.

Foryś I. [2010], Wykorzystanie metod taksonomicznych do wyboru obiektów podobnych w procesie wyceny lokali mieszkalnych, ,Studia i Materiały Towarzystwa Naukowego Nieruchomości", vol. 18, nr 1.

Foryś I. [2011], Społeczno-gospodarcze determinanty rozwoju rynku mieszkaniowego w Polsce. Ujęcie ilościowe, Wydawnictwo Uniwersytetu Szczecińskiego, Szczecin.

Gordon A.D. [1999], Classification, Chapman \& Hall/CRC, Boca Raton.

Malina A. [2004], Wielowymiarowa analiza przestrzennego zróżnicowania struktury gospodarki Polski według województw, Zeszyty Naukowe, Seria specjalna: Monografie, nr 162, Wydawnictwo Akademii Ekonomicznej w Krakowie, Kraków.

Metody statystycznej analizy wielowymiarowej w badaniach marketingowych [2004], red. E. Gatnar, M. Walesiak, Wydawnictwo Akademii Ekonomicznej im. Oskara Langego we Wrocławiu, Wrocław.

Młodak A., [2006], Analiza taksonomiczna w statystyce regionalnej, Difin, Warszawa.

Strahl D. [1986], Podobieństwo struktur jako kryterium wyboru wzorca, „Prace Naukowe Akademii Ekonomicznej we Wrocławiu", nr 281.

Wędrowska E. [2012], Miary entropii i dywergencji $w$ analizie struktur, Wydawnictwo Uniwersytetu Warmińsko-Mazurskiego w Olsztynie, Olsztyn.

Zyga J., [2009], Podobieństwo w wycenie nieruchomości, „Budownictwo i Architektura”, vol. $5, \mathrm{nr} 2$.

\section{Comparison of the Structure of Apartments Sold in Two Cities in Northwest Poland}

(Abstract)

When evaluating a property, an appraiser should find a real estate market that is similar to the market the evaluated property is on. While similar markets will sometimes not be found in the same city, demographic and economic ratios can be used as criterion of similarity. The analysis and comparison of the structures of apartments sold on two hous- 
ing markets could also help in confirming the similarity of markets. The similarity of markets could be used in further analyses and property evaluations.

The aim of the research is to compare the structures of apartments sold in cities according to the apartments' attributes, including date of transaction, price, area and location in the city. The housing markets in Szczecin and Bydgoszcz are compared. These cities have a similar number of transactions on their housing markets and have populations of similar size. The data come from notarial deeds for transactions on the secondary housing markets in Szczecin and Bydgoszcz. The analysis is done for two years: 2009, the first year of crisis on the real estate market, and 2015, the year with the most recent data. Measures of entropy and the similarities of the structures are applied.

Keywords: housing market, structure comparison, entropy measures, valuation. 